\title{
INTERSTITIAL PNEUMONITIS IN CANINE VISCERAL LEISHMANIASIS
}

M. I. S. DUarte (1), M. D. Laurenti (2), V. L. BRanda NUNes (3), A. F. Rego JR. (4), E. T. OSHRo (5) C. E. P. CORBETT (1)

\section{S U M M A R Y}

Forty-one naturally infected dogs with visceral leishmaniasis from an urban area of Corumbá (Mato Grosso do Sul-BRAzIL) were studied and three types of lung involvement due to visceral leishmaniasis were characterized; a cellular, a cellular-fibrotic and a fibrotic type. These types seem to represent a sequential evolutive process. Visceral leishmaniasis frequently causes an interstitial pneu. monitis in naturally infected dogs $(\mathbf{8 0 . 5 \% )}$ ) as well as in man and experimentally infected hamsters

KEY WORDS: Visceral leishmaniasis; Interstitital pneumonitis; Canine pathology.

\section{N T RO D U C T I O N}

Foci of canine visceral leishmaniasis in Brazil, together with human cases, suggest that the dog is an important host of this protozoan disease. In the Northeast of Brazil the disease is endemic (ALENCAR, 1959 3; ALENCAR \& CUNHA, $1983^{4}$; BRENER, $1957^{10}$; DEANE \& DEANE, 1954 16; DEANE \& DEANE, 1955 17; ESPINOLA GUEDES et al., 197422 and SHERLOCK \& ALMEIDA, 1969 33). Nevertheless, outbreaks of the disease have also been well characterized in other regions (I Reunião Nacional sobre Pesquisa em Leishmaniose, 1984 ${ }^{32}$ ). Nowadays new human cases have been report. ed in Brazil. New cases have been reported in São Luis (Maranhão), in the outskirts of Maceió (Alagoas), in Paraíba, in Rio de Janeiro and in Corumbá (Mato Grosso do Sul) (I Reunião Nacional sobre Pesquisa em Leishmaniose, 1984 ${ }^{34}$ ).
The histopathology of canine visceral leishmaniasis has not been well characterized so far. Few references have been reported on the identification of parasites in the tissue along with infiltrates of mononuclear inflammatory cells in different organs (ADLER \& TCHERMONORETZ, 1946 2; ALENCAR, 19593 , ALVARENGA, 1960 5; ANDERSON et al. 1980 6; BRENER, 1957 10; CORBIEL et al, 1976 13; GEORGE et al, $1976{ }^{24}$ ). Interstitial pneumonitis and considered to be highly suggestive of visceral leishmaniasis (DUARTE et al, 1985 21) described in man (ANDRADE, $1959^{\circ}$ and RASO \& SIQUEIRA, 1964 ${ }^{31}$ ) has been found in $62.5 \%$ of the autopsy material (CHASSOT et al, 1983 11).

The histopathology of the lung has not been characterized so far in canine visceral

(1) Professor Assistente Doutor do Departamento de Patologı da Faculdade de Medicina da Universidade de São Paulo, Av. Dr. Arnaldo, 455, 01246, Sāo Paulo, Brasil

(2) Biomédica - Laboratório de Patologia de Moléstias Infecciosas đa Faculdade de Medioina da Universidade de São Paulo

(3) Professora Titular de Parasiotlogla e Parasitologia Clinica do Departamento de Patologia do Centro de Ciências Biológicas e da Saúde da Universidade Foderal do Mato Grosso do Sul.

(4) Médico Veterinário - IAGRO - Departamento de Vigilância Agropecuária de Corumbá, Mato Grosso do Sul, Brasil

(5) Médica Veterinária da Universidade Foderal do Mato Grosso do Sul, Brasil 
DUARTE, M. I. S.; LAURENTI, M. D.; BRANDAO NUNES, V. L.; REGO JR., A. F.; OSHIRO, E. T. \& CORBETT, C. E. P. - Interstitial pneumonitis in canine visceral leishmaniasis. Rev. Inst. Med. trop. São Paulo, 28:431-436, 1986. 1986.

leishmaniasis. Rare cases of lung involvement were described stressing mainly the parasite's identification and concomitant secondary infections. TRYPHONAS, $1977^{34}$, described a marked septal thickening characterizing an interstitial pneumonitis in the lungs of a dog living in Spain for two years together with other visceral changes. In this case no parasites were found. In 1980, ANDERSON ${ }^{6}$, found a diffuse multifocal septal thickening in the lungs of a dog from Texas with infiltration of plasma cells and histiocytes, some of which containing leishmania.

An outbreak of visceral leishmaniasis in Corumbá involving both men and dogs stimulated us to study the lungs of naturally infected dogs in order to characterize the histopatho. logical changes due to the disease. Efforts were also directed to identify a possible relation between lesions found in dogs and those seen in man and hamsters.

\section{MATERIAL AND METHODS}

Forty-one dogs from Corumbá, presenting the usual clinical picture of the chronic phase of visceral leishmaniasis (ADLER \& THEO-

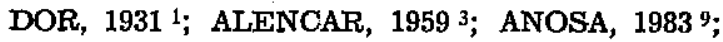
BRENER, $1957^{10}$; COVALEDA, HIVES \& SOLER DURALL, 1951 14; CUNHA, 1938 15; DONA. TIEN \& LESTOQUARD, 1935 18; FAURE-BROC, $1936{ }^{23}$; JOYEX \& SANDET, 1938 25; KEENAN et al, 1984 26; LANNOTTE et al, 1979 27; LEN. NOX, SMART \& LITTLE, 1972 23; MENDONZA et al, $1983^{29}$; QUEIROZ, $1959^{30}$ and SHERLOCK \& ALMEIDA, 1969 33) were studied. The animals presented wide-spread alopecia and furfuraceous scaling mainly around the nose and eyes, cutaneous ulcers, keratitis, long nails, low weight, high body temperatures, adenomegaly, arthritis and sometimes paralysis of the hindlegs. Identification of the agent was done by examination of skin lesions, spleen and liver smears; by parasite isolation in culture medium (NNN); by inoculation in hamsters followed in some cases by leishmania typing (isoenzymes and monoclonal antibodies - J. J. SHAW The Wellcome Parasitology Unit. Belém, Pará, BR). Parasites were also found in histopatho. logical specimens from liver, spleen, lymph nodes and skin. All organs showed histopathological changes compatible with visceral leishmaniasis.
Fragments from lungs and other organs were collected through autopsy of the dogs and fixed in phosphate buffered saline containing $10 \%$ formalin.

Lung fragments ( $4 \mu$ thick) were stained by the hematoxylin-eosin, Masson's and Picro. sirius methods (CONSTANTINE \& MOURAY, $\left.1968{ }^{12}\right)$. The picro-sirius stained slides were observed under polarized light in an optical microscope.

Four dogs from the same place, without clinical signs of visceral leishmaniasis, showed neither lung nor any other organ changes which could be related to the infection. These dogs were used is controls.

\section{RESULTS}

Histopathological pulmonary changes were found in 33 out of 41 cases. The main lesion was septal thickening which intensity and distribution varied from case to case with no preference for any specific area of the lung.

Based on the characteristics of the septal thickening changes were classified in three types:

1. "Cellular" (Figure 1): in which the septal thickening was due mainly to a mononuclear cells infiltrate (lymphocytes, plasma cells, macrophages and cells with fat-containing vacuolated cytoplasm). The septal capillaries showed congestion with no en. dothelial changes. Pneumocytes I and II of the alveolar lining were preserved. The intensity of the mononuclear cell infiltrate varied from area to area in the same cases and no correlation with any region was seen. There was at least one area of preserved parenchyma in all cases even in those with large involvement. Vicariant emphysema was found in the most severe cases.

2. "Fibrotic-cellular" (Figure 2): in which septal changes resulted from infiltration of mononuclear cells, as in the cellular type, associated with small bands of fibrous tissue. Septal capillaries and alveolar lining showed no changes. Vicariant emphysema was present in areas of higher involvement. 
DUARTE, M. I. S.; LAURENTI. M. D.; BRANDAO NUNES, V. L.; REGO JR., A. P.; OSHIRO, E. T. \& CORBETT, C. E. P. - Interstitial pneumonitis in canine visceral leishmaniasis. Rev. Inst. Med. trop. Säe Paulo, 28:431-436, 1986. 1986

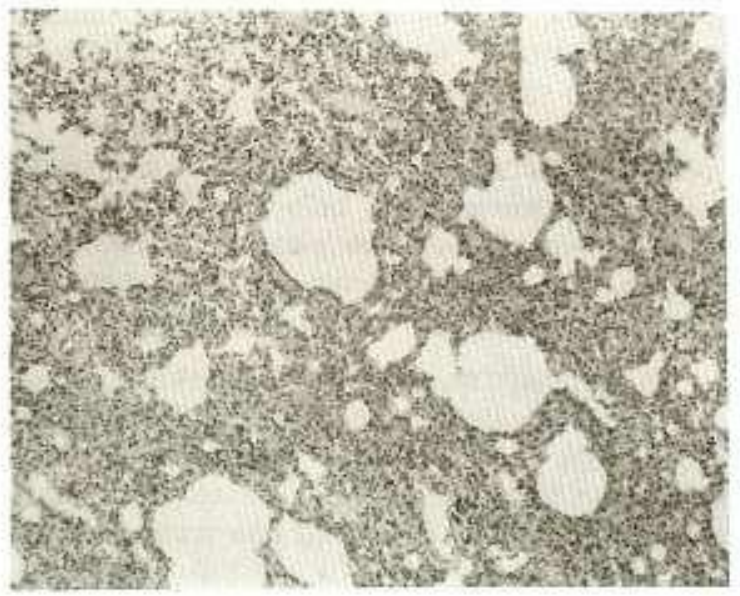

Pig. 1 - Cellular type: septal thickening by mononuclear coll infiltrate. HE X 100.

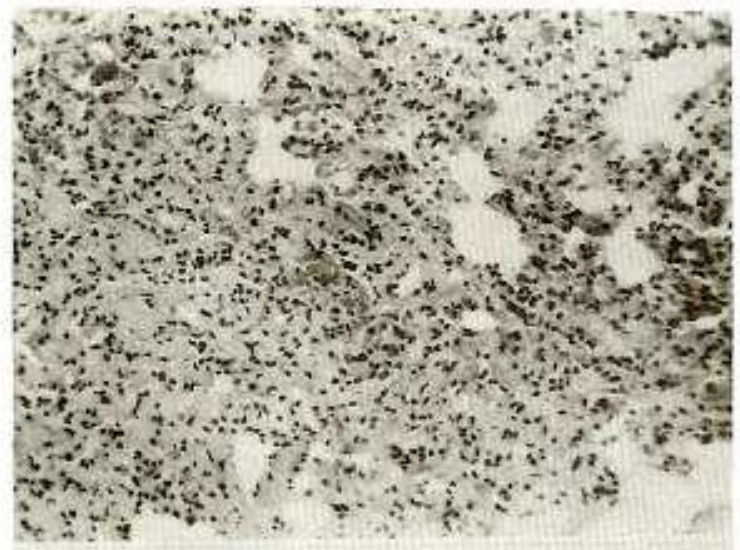

Fig. 2 - Cellular-fibrotic type: detail of the mononuclear cells infiltrate together with delicate bands of fibrous tissue within the septum. HE $\mathrm{X} 460$.

3. "Fibrotic": bands of fibrous tissue thicken. ing the intra alveolar septum and involving large areas of the lung parenchyma were characteristic of this type. The alveolar lumen was preserved. Fibrosis was accom. panied by discrete mono iuclear cell infil. trate without alterations 0 capillaries and pneumocytes. Vicariant emphysema was related with the more fibrotic areas. Fibrosis, even thinner ones, could be demonstrated through the Picrosirius stain method when examined under polarized ligh (Figure 3 and 4).

In the whole there were no epithelial bronchial changes but in 2 cases there were discrete mononuclear cells infiltrate in the corium.

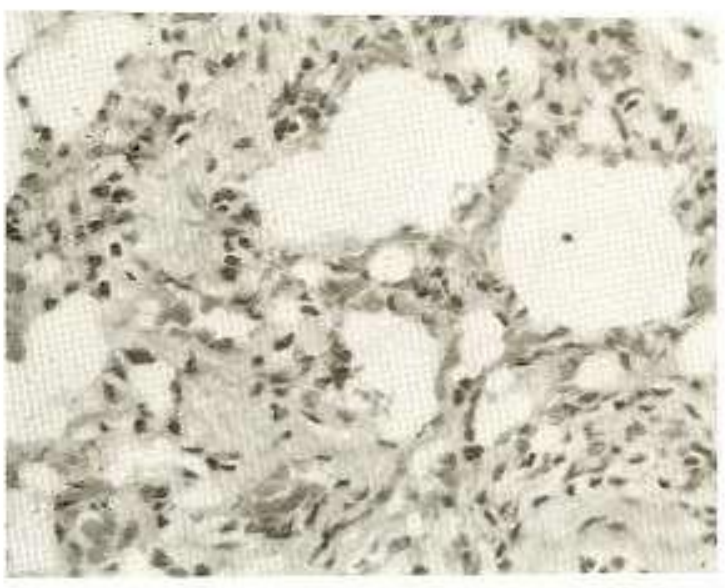

Fig. 3 - Fibrotic type: the fibrous tissue is much mure evident than the mononuclear cell infilitrate. HE $\mathrm{X}$ o 0 .

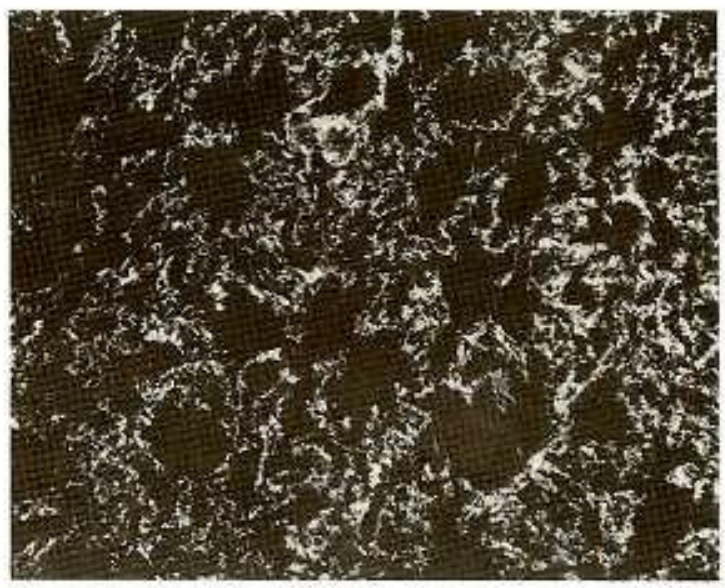

Fig. 4 - Lang tissue treated with Picro-sirius stain and absorved under polarized light, siowing septal thickening due to collagen fibers. $X 100$.

The alveolar lumen had neither edems or exsudation.

Amastigctes were found within the cytoplasis of either septal or alveolar macropha. ges only in the lungs of 3 of the cases with interstitial pneumonitis. However, numerous amastigotes were found in other tissuts examined, (skin, lymph nodes, spleen and liver). Eight of the cases showed no pulmonary histopathological changes.

\section{DISCUSSION}

No systematical reference on the pulmo. nary involvement in dogs with visceral leishmaniasis was found in the literature. There 
DUARTE, M. I. S.; LAURENTI, M. D.; BRANDAO NUNES, V. L.; REGO JR., A. F.; OSHIRO, E. T. \& CORBETT, C. E. P. - Interstitial pneumonitis in canine visceral leishmaniasis. Rev. Inst. Med. trop. Sāo Paulo, 28:431-436, 1986. 1986.

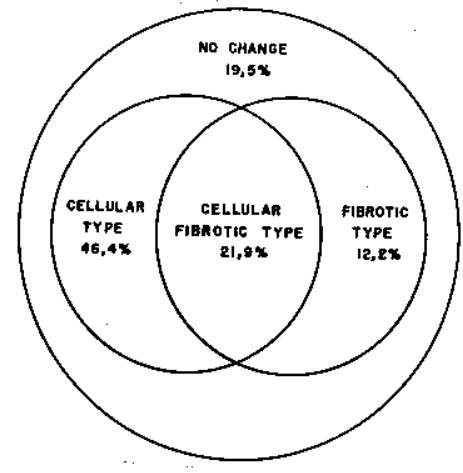

Fig. 5 - Distribution of the histopathological types of the septal thickening of the lung in 41 visceral leishmaniasis dogs.

are few reports describing bronchopneumonia as secondary infections and also few references on other pulmonary changes concurrent with this protozoan disease. GEORGE, in $1976^{24}$, related "focal interstitial thickening" in one dog, TRYPHONAS, in $1977^{34}$ and ANDERSON in $1980^{6}$, also described an "interstitial pneumonitis" in a dog, evading to suggest any relation to visceral leishmaniasis in spite of the identification of leishmania done by Anderson in the lung.

In this work we tried to define the pulmonary changes possible to occur in visceral leismaniasis by studying naturally infected dogs, caught during an urban epidemic outbreak of visceral leishmaniasis in Corumbá (Mato Grosso do Sul, BR). All animals had clinical signs of the disease and parasites were identified either in smears and histological tissue sections from their organs, by isolation in culture medium or by inoculation in hamsters.

It is important to point out that all animals had histopathological characteristics of visceral leishmaniasis showing no other pulmonary changes as bronchopneumonia or any other alveolar lumen involvement.

The pulmonary changes found in naturally infected dogs were frequent $(80,5 \%)$ and characterized by an interstitial pneumonitis which we believe to be related to visceral leishmaniasis.

The different patterns of septal thickening were described according to the prominence of elements participating in each case. The cellular type $(46,49 \%)$ is due mainly to a mononuclear cell infiltrate in the septum. The cellular-fibrotic type $(21,9 \%)$ presents both mononuclear cell infiltrate and fibrosis. Finally, in the fibrotic type $(12,2 \%)$, the septal changes originate from fibrosis. We believe that all three types represent evolutive phases of the same process. The fibrotic phase is subsequent to a previous septal inflammatory process.

In man, ANDRADE, $1958^{7}$ and $1959^{8}$, found interstitial pneumonitis in 3 out of 5 autopsies of patients with visceral leishmaniasis and considered it as part of the disease. RASO and SIQUEIRA, $1964^{31}$, described one more case of interstitial pneumonitis. Interstitial pneumonitis was found in $62,5 \%$ of autopsies and foci of septal fibrosis in $30 \%$ (DUARTE, M.I.S. -unpublished data). Amastigotes were rarelly found (CHASSOT et al, 1983 an immunoenzimatic method (PAP- peroxidase anti-peroxidase) and specific antibodies, particulate antigenic material and/or amastigotes was found in the interalveolar septum, whenever interstitial pneumonitis was present (DUARTE et al, $1985^{21}$ ). This fact confirms that septal changes are due to the disease. A few PAP tests in dog lung performed in our laboratory, showed the same results.

We have already demonstrated an interstitial pneumonitis developing in distinct stages in hamsters experimentally infected with $\mathbf{L}$. domovani (DUARTE, 1979 19; DUARTE e COR. BETT, $1984{ }^{20}$ ). There was a exsudative stage of short duration followed by cellular proliferation and later on, by fibrosis. All sequential changes between cellular proliferation and fibrosis could be characterized as part of the same process.

Therefore visceral leishmaniasis often determines an interstitial pneumonitis, either in man, or in naturally infected dogs, or even experimentally infected hamsters. The histopatological changes seen in each case depend on the evolution of the process. There is also a similarity of histopathological changes in the three species: man, dog and hamster. Interstitial pneumonitis seems to be the pulmonary representation of an interstitial pathology of visceral leishmaniasis, also seen in others organs with interstitial lesions such as liver and kidneys. 
DUARTE, M. I. S.; LAURENTI, M. D.; BRANDAO NUNES, v. L.; REGO JR., A. F.; OSHIRO, E. T. \& CORBETT, C. E. P. - Interstitial pneumonitis in canine visceral leishmaniasis. Rev. Inst. Med. trop. São Paulo, 28:431-436, 1986. 1986.

\section{RESUMO}

\section{Pneumonia intersticial na leishmaniose visceral canina}

Estudamos 41 cães naturalmente infectados com leishmaniose visceral, provenientes da área urbana de Corumbá (Mato Grosso do Sul, BR) e caracterizamos 3 tipos de acometimento pulmonar devido à leishmaniose visceral: celular, fibrótico-celular e fibrótico. Estes tipos pa recem representar um processo evolutivo sequiencial. A leishmaniose visceral causa uma pneumonite intersticial em $80.5 \%$ dos cães naturalmente infectados à semelhança do que ocorre no homem e em hamsteres experimentalmente infectados.

\section{ACKNOWLEDGEMENTS}

This work was supported by FINEP: 43/83/0006/00.

\section{REFERENCES}

1. ADLER, S. \& THEODOR, O. - Skin infection in canine visceral leishmaniasis. Brit. med. J., 2: 1179, 1931

2. ADLER, \&. \& TCHERNOMRETZ, I. - Failure to cure natural canine visceral leishmaniasis. Ann. trop. Med. Parasit., 40: 320-324, 1946.

3. ALENCAR, I. E. - Calazar canino. Contribuição para - estudo da opidemiologia do calazar no Brasil. Fortaleza. Imprenșa Oficial, 1959.

4. ALENCAR, J. E. \& CUNHA, R. B. - Survey of canine Kala-azar in Ceará. Latest results. Rev. bras. Malar., 15: 391-403, 1983.

5. ALVARENGA, R. J. - Histopathology of Chagas di. sease and of Kala-azar in naturally infected dogs. Hospital (Rio de J.), 57: 23-40, 1960.

6. ANDERSON, D. C.; BUCKKER, R. G.; GLENN, B. L. \& MacVEAN, D. W. - Endemic canine leishmaniasis. Vet. Path., 17: 94-96, 1980.

7. ANDRADE, Z. A. - A patologia da Ieishmaniose visceral (Kala-azar). Salvador, 1958. (Tese - Faculdade de Medicina da Universidade da Bahia).

8. ANDRADE, Z. A. - Pneumonite intersticial no calazar. Hospital (Rio de J.), 55: 71, 1959.

9. ANOSA, V. O. \& IDOWU, A. L. - The clinico-haematological features and pathology of leishmaniasis in a dog in Nigeria. Zbl. Vet. Med. B., 30: 600-608, 1983.
10. BRENER, Z. - Calazar canino em Minas Gerais. Belo Horizonte, 1957. (T'ese de doutoramento - Faculdade de Medilona da Universidade de Minas Gerais).

11. CHASSOT, C. A.; MORAIS, C. F.; DUARTE, M. I. S. \& AMATO NETO, V. - Pneumonite intersticial da leishmaniose visceral: estudo histopatológico em necrópsias. In: CONGRESSO DA SOCIEDADE BRASILEIRA DE MEDICINA TROPICAL, 19., Rio de Janeiro, 1983. Pro grama e resumos. Rio de Janeiro, Imprina, 1983. p. 63.

12. CONSTANTINE, V. S. \& MOWRY, R. W. - Selective staining of human dermall collagen. Ir. The use of picrosirius red F3BA with polarization microscopy. J. invest. Derm., 50: 419-423, 1968.

13. CORBIEL, L. B.; WRIGHT-GEORGE, J.; SHIVELX, J. N.; DUNCAN, J. R.; IA MOTTE, G. B. \& SCHULTZ R. D. - Canine visceral leishmaniasis with amyloidosis: an immunopathological case study. Cln. Immunol. Im. munopath., 6: 165-173, 1976.

14. COVALEDA, J.; HIVES, J. \& SOLER DURALL, C. Canine leishmaniasis in Barcelona; preliminary report. Rev. Sanid. Hig. Públ., 25; 710-712, 1951.

15. CUNHA, A. M. - Infeccão da pele na leishmaniose visceral experimental do cão. Brasill-méd., 52: 1071 1072, 1998 .

16. DEANE, L. M. \& DEANE, M. P. - Finding of dogs naturally infected with Leishmania donovani in Ceara. Hospital (Rio de J.), 45: 703-707, 1954.

17. DEANE, L. M. \& DEANE, M. P. - Urban visceral leishmaniasis in dog and man in Sobral, Ceará. Hospital (Rio de J.), 47: 75-87, 1955.

18. DONATIEN, A. \& LESTOQUARD, F. - Notes sur la leishmaniose viscérále canine. Bull. Soc. Path. exot., 6: $426-431,1935$

19. DUARTE, M. I. S. - Pneumonite intersticial no calazar. São Paulo, 1979. (Tese de doutoramento $-\mathrm{Fa}$ culdade de Medicina da Universidade de São Paulo).

20. DUARTE, M. I. S. \& CORBETT, C. E. P. - Histopathological and ultrastructural aspects of intestitial pneumonitis of experimental visceral leishmaniasis. Trans. roy. Soc. trop. Med. Hyg., 78: 683-688, 1984.

21. DUARTE, M. I. S.; MATTA, V. L. R.; GOTO, H.; ALVES, V. A. F. \& CORBETT, C. E. P. - Pneumopatia na leishmaniose visceral humana: detecçăo de amastigotas e seus produtos em pulmäo por método imunoenzimático. In: CONGRESSO DA SOCIEDADE BRASILEIRA DE MEDICINA TROPICAL, 21., São Paulo, 1985. Programa e resumos. São Paulo, Balieiro Editores, 1985. p. 106-107.

22. ESPINOLA GUEDES, G.; MAROYA, A.; CHAVES, E.; ESTELIO, ; CUNHA; M. J. \& ARCOVERDE, S. Calazar no litoral do Estado da Paraíba, Brasil. Encontro de 70 casos humanos e 16 caninos. Rev. Inst. Med. trop. S. Pulo, 16: 265-269, 1974. 
DUARTE, M. I. S.; LAURENTI, M. D.; BRANDAO NUNES, V. I.; REgO JR., A. F.; OSkIRO, E. T. \& CORBETT. C. E. P. - Interstitial pneumonitis in canine visceral leishmaniasis. Rev, Inst. Med, trop. Säe Paulo, 28:431-436, 1986. 1986.

23. FAURE, B. G. - La Leishmaniose canine (Sa frêquence son diagnostic clinique et biologique, son traitment). Biol. méd. (Paris), 26: 113-158, 1936.

34. GEORGE, J. W.; NIEISEN, S. W.; SHIVELT, J. N.; HOPES, S. \& MROZ, S. - Canine leishmaniasis with amyloidosis. Vet. Path., 13: 365-373, 1976.

25. JOYEUX, C. \& SANDET, J. - Observations sur la leishmaniose canine méditerranéenne. Bull. Soc. Path. exot., 31: $487,1938$.

26. KEENA, C. M.; HENRICKS, L. D.; LIGHTNER, L.; WEBSTER, J. K. \& JOHNSON, A. J. - Visceral leishmaniasis in the germann shepherd dog. I - Infection clinical disease and clinical pathology. II - Pathology. Vet. Path., 21: 74-86, 1984.

27. LANNOSTTE, G.; RIOUX, J. A.; PERIERES, J. \& VOLLHARDT, Y. - Developmental stages and clinical characterization of canine leishmaniasis in relation to epidemiology. Ana. Parasit. hum. comp., 54: 277-295, 1979.

28. LENNOX, W. J.; SMART, M. E. \& LITTLE, P. B. Case report. Canine leishmaniasis in Canada. Canad. vet. J., 13: 188-190, 1972.

28. MENDONZA, L.; PODETTI, M.; CHAVEZ, F. \& ZELEDON, R. - Visceral leishmaniasis in a dog intro. duced into Rosta Rica. Trans. roy. Soc. trop. Med. Hyg., 7r: 283-284, 1983.

30. QUEIROZ, J. M. - Lesions of the eyejall and adnexa in canine Kala-azar. Rev. Ass. med. 'uras,, 5: 304-309, 1959.

31. RASO, P. \& SIQUEIRA, J. T. - Subsidio ao conheclmento da anatomia patológica da leishmaniose visceral, com especial referência às lesōes pulmonares e cardiacas. Hospital (Rio de J.), 65: 144-163, 1964.

32. REUNIAO NACIONAL SOBRE PESQUISA FM LEISEMANIOSE, I. - Faculdade de Medicina da Universi. dade de São Paulo, Departamento de Patologla, São Paulo, Brasil, 1984.

33. SHERLOCK, J. A. \& ALMEIDA, S, P. - Findings on Kala-azar in Jacobina, Bahia. II - Canine lisshmaniasis. Rev. bras. Malar., 21: 535-539, 1969.

34. TRYPHONAS, L.; ZAWDZKA, Z.; BERNARD, M. A. \& JANZEN, E. A. - Visceral leishmariasis in a dog: clinical hematological and pathologica! observations. Canad. J. comp. Med., 41: 1-12, 1977.

Recebido para publicaçäo em 4/12/85. 